\title{
Carbonaceous and Protein Constituents in Dairy Wastewater Lead to a Differentiated Current Generation in Microbial Fuel Cells (MFCs)
}

\author{
Bibiana Cercado, ${ }^{*}$ Ana Laura Vega-Guerrero, ${ }^{1}$ Francisco Rodríguez-Valadez, ${ }^{1}$ José Luis \\ Hernández- López, ${ }^{1}$ Luis Felipe Cházaro-Ruiz, ${ }^{2}$ Marie-Line Délia, ${ }^{3}$ and Alain Bergel ${ }^{3}$
}

${ }^{1}$ Centro de Investigación y Desarrollo Tecnológico en Electroquímica, S.C. Parque Tecnológico Querétaro S/N, Sanfandila, Pedro Escobedo, Querétaro, C.P. 76703, Mexico.bcercado@cideteq.mx.

2 Instituto Potosino de Investigación Científica y Tecnológica A.C. División de Ciencias Ambientales. Camino a la Presa San José No. 2055, Lomas 4ª Sección, 78216 San Luis Potosí, San Luis Potosí, Mexico.

${ }^{3}$ Laboratoire de Génie Chimique (LGC), CNRS, Université de Toulouse (INPT), 4 allée Emile Monso, BP 84234, 31432 Toulouse, France.

Received January 20"th 2014; Accepted April 2nd 2014.

\begin{abstract}
The effect of real dairy wastewater (DWW) additions on the current density generated by a bioanode was evaluated in a half cell configuration under potentiostatic control, thus simulating the anodic chamber of a Microbial Fuel Cell. Low substrate additions increased current density up to $1655 \pm 136 \mathrm{~mA} \mathrm{~m}^{-2}$, forming a two-current peak pattern. Then the system was tested with a casein-lactose synthetic media. A high protein concentration reduced the current density; individual compounds led to the highest current $\left(330.5 \mathrm{~mA} \mathrm{~m}^{-2}\right.$ with casein; $1276 \mathrm{~mA} \mathrm{~m}^{-2}$ with lactose). Moreover, the protein reduced the current start up time.

Key words: Microbial fuel cell, dairy wastewater, bioanode, current
\end{abstract} density, casein, lactose.

\section{Introduction}

The microbial fuel cells (MFC) are devices that convert the chemical energy in organic matter into electrical energy by the catalytic activity of electrochemical active microorganisms. MFCs have been used for simultaneous generation of electricity and wastewater treatment; more recently energy vectors such as hydrogen or chemical products are produced using bioelectrochemical systems [1].

The Fig. 1A schematizes basics of MFC operation. Two compartments, anodic and cathodic are joined by a selective membrane that allows the ion $\mathrm{H}^{+}$diffusion from the anolyte toward the catolyte. Bacteria consume organic matter in the anolyte forming an electrochemically active biofilm on the anode. The electrons produced by the microbial metabolic activities are transferred to the anode, and then circulate through an external connection to the cathode producing an electrical current. The electrical circuit is closed on the cathode, where the ions $\mathrm{H}^{+}$and the arriving electrons reduce the oxidant present in the catolyte, generally the oxygen. Because of the variety of wastewater that can be used as fuel or substrate, research on food industrial wastewater plays a real and practical role nowadays.

A review on the use of industrial wastewater has been reported by Pant et al. [2]. Although real industrial wastewater
Resumen. Se evaluó la densidad de corriente de un bioánodo con adiciones de agua residual lacto-alimenticia. A menor volumen de substrato adicionado, se observó mayor producción de densidad de corriente $\left(1655 \pm 136 \mathrm{~mA} \mathrm{~m}^{-2}\right)$, con un patrón de dos picos de corriente. El sistema evaluado con un medio sintético de caseína-lactosa mostró que una alta concentración de proteína afectó negativamente la corriente producida; los componentes individuales generaron los valores más altos de corriente $\left(330.5 \mathrm{~mA} \mathrm{~m}^{-2}\right.$ con caseína; $1276 \mathrm{~mA}$ $\mathrm{m}^{-2}$ con lactosa). Adicionalmente la proteína favoreció el inicio de generación de corriente.

Palabras clave: Celda de combustible microbiana, agua residual de industria lacto-alimenticia, bioánodo, densidad de corriente, caseína, lactosa.

is a complex mixture, investigations on the effect of its compounds on MFCs performance are seldom reported. Very frequently carbonaceous substrates such as acetate, are preferred to start up and operate MFCs, moreover research on the effect of proteins on MFCs performance are less frequent, but it has been reported the cysteine effect on current generation [3], and the effect of protein content in meat pack industrial wastewater on the power generation in MFCs [4].

In this respect, dairy wastewater (DWW) has been evaluated for energy generation in various systems (Table 1). The different MFC design, inoculum, and DWW characteristics result in a current density range from 0.037 to $2250 \mathrm{~mA} \mathrm{~m}^{-2}$. Based

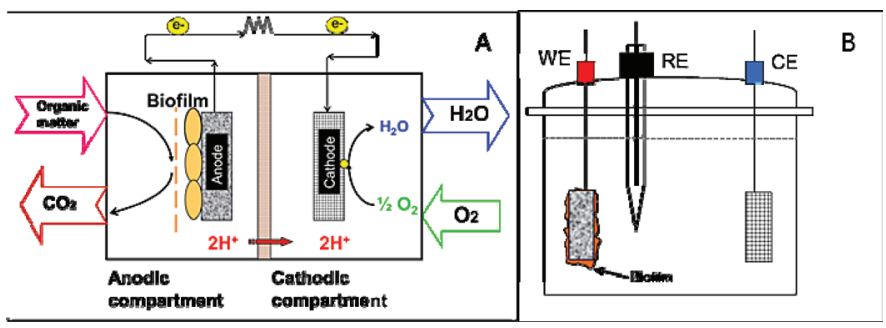

Figure 1. A) Microbial fuel cell components and its basic operation. B) Schematic view of the experimental three-electrode set-up. WE working electrode, RE reference electrode, and CE counter-electrode. 
on these broad differences, it was remarked that the necessity of more investigation on the effect of DWW compounds on the current generation in MFC systems.

In the present work, the effect of real DWW additions on the current density generated by a bioanode was evaluated in a half cell configuration under potentiostatic control, thus the anodic chamber of a MFC. In the second stage, the effect of individual DWW compounds on current generation was evaluated using a synthetic media composed by casein and lactose mixtures. Finally, it was identified that the casein-lactose mixture held the highest current density.

\section{Experimental}

\section{Inoculum source and experimental setup}

The inoculum source was obtained from compost leachate. It was prepared by mixing $1 \mathrm{~L}$ yard compost with a $10 \mathrm{mM} \mathrm{NaCl}$ solution to reach a $3 \mathrm{~L}$ final volume. The mixture was agitated for $12 \mathrm{~h}$ and then filtered through a felt cloth. The filtrate was used as an inoculum, which had the following characteristics: $1.7 \mathrm{~g} \mathrm{~L}^{-1}$ protein concentration, $\mathrm{pH} 7.56$, and $2.56 \mathrm{mS} \mathrm{cm}^{-1}$ conductivity.

Bioanode formation was achieved under potentiostatic control [5, 6]. A graphite felt electrode $(2 \mathrm{~cm} \times 2 \mathrm{~cm}$, Carbone Lorraine) was placed in a three-electrode electrochemical cell containing $150 \mathrm{~mL}$ compost leachate, then a potential equal to $+0.1 \mathrm{~V} / \mathrm{SCE}$ was imposed during 1-2 $\mathrm{d}$ with a potenciostat/ galvanostat BioLogic SAS (software EC-Lab ver.10.14). The applied potential was selected after results showed the anode potential evolution in a two-chamber MFC fed with DWW [5]. The electrochemical cells were maintained in a water bath at $40{ }^{\circ} \mathrm{C}$ (Julabo). A Standard calomel electrode (SCE) was used as reference and a platinum mesh $(2 \mathrm{~cm} \times 2 \mathrm{~cm})$ as a counterelectrode (Fig. 1B).

\section{Real dairy wastewater experiments}

The carbon felt electrodes were pretreated by dairy waste impregnation in order to promote biofilm development on the nutritious layer [7]. The electrodes were immersed in a container with DWW, and sonicated for 10 min to enhance fibers and waste contact. The pretreated electrodes were placed in the electrochemical cells containing compost lixiviates and the biofilm was developed for 1 day at a $+0.1 \mathrm{~V} / \mathrm{SCE}$ fixed potential. Once the bioanode was formed, 100, 300, 900 and $2500 \mu \mathrm{L}$ of DWW were added in the cells. DWW had the following characteristics: $\mathrm{pH} 3.6-4.8,4-6 \mathrm{mS} \mathrm{cm}{ }^{-1}$ conductivity, and $136.5 \pm$ $37.9 \mathrm{~g} \mathrm{~L}^{-1}$ chemical oxygen demand (COD). Current generation was determined in duplicate cells for each condition by $14 \mathrm{~d}$.

\section{Casein-Lactose synthetic media experiments}

Biofilm was developed for $2 \mathrm{~d}$ on carbon felt electrodes immersed in compost lixiviate at $+0.1 \mathrm{~V} / \mathrm{SCE}$ fixed potential. Once the bioanodes were formed, they were transferred to electrochemical cells containing the casein-lactose mixtures.

The casein-lactose mixtures were prepared in a humic acidsolution $\left(1.5 \mathrm{~g} \mathrm{~L}^{-1}\right)$ to simulate compost lixiviate [17]. Casein was dosed at $0,1.5$, and $15 \mathrm{~g} \mathrm{~L}^{-1}$ concentrations, and lactose was at $0,0.5,5 \mathrm{~g} \mathrm{~L}^{-1}$ concentrations, then the 9 casein-lactose mixtures were prepared. The middle concentrations $\left(1.5 \mathrm{~g} \mathrm{~L}^{-1}\right.$ casein; $0.5 \mathrm{~g} \mathrm{~L}^{-1}$ lactose) were selected according to the real concentrations in DWW.

\section{Chemical and electrochemical analysis}

The $\mathrm{pH}$ and conductivity of solutions were measured with a potentiometer (CG 882 Schott Gerate $\mathrm{GmbH}$ ) and a conductimeter (Metrohm 660). Wastewater parameters COD and total organic carbon (TOC) were determined with the Hach Company

Table 1. Comparison of MFCs fed with dairy compounds or DWW. Performance reported from polarization curves.

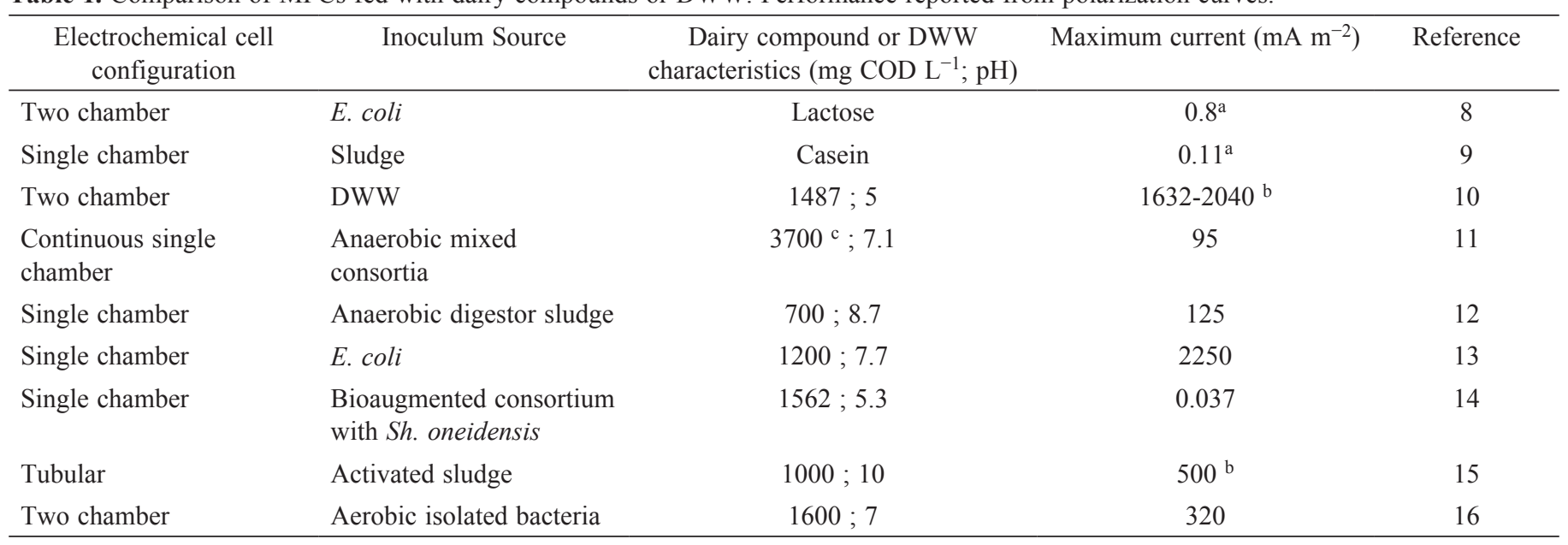

${ }^{a}$ Data reported in $\mathrm{mA}$. No additional information available for current density estimation.

${ }^{\mathrm{b}}$ Calculated form reported data in the experimental section.

c. Organic loading rate $2.67 \mathrm{~kg} \mathrm{COD} \mathrm{m}^{-3}$ 
kit 8000 and 10128 methods respectively. Briefly, for the COD reflux method, $2 \mathrm{~mL}$ sample were incubated during $2 \mathrm{~h}$ at 550 ${ }^{\circ} \mathrm{C}$ in a reaction tube containing an oxidant solution $\left(\mathrm{K}_{2} \mathrm{CrO}_{7}\right.$ in $\mathrm{H}_{2} \mathrm{SO}_{4}$ ). Then the chromic ion was quantified at $600 \mathrm{~nm}$ against a reaction blank in a spectrophotometer (HACH France SAS). TOC determination was based on the organic carbon oxidation by persulfate in acid medium, and the color change of the $\mathrm{pH}$ indicator measured at 598 and $430 \mathrm{~nm}$. The lactose was quantified by an enzymatic method following the supplier indications (Boehringer Mannheim/R-Biopharm UV method). Briefly, the lactose was hydrolyzed to galactose and glucose, then the galactose was oxidized by NAD+, and the NADH formed was quantified at $340 \mathrm{~nm}$. The casein was monitored by the Lowry colorimetric method for protein quantification [18].

Current generation was followed by chronoamperometry at fixed potential $+0.1 \mathrm{~V} / \mathrm{SCE}$ along 13-15 d tests. Experimental charge was calculated from chronoamperograms by integration of the current along the experimental period.

\section{Results and Discussion}

\section{Current generation with real dairy wastewater}

The current density during biofilm development $(0-1 \mathrm{~d})$ was stabilized in the range from 200 to $500 \mathrm{~mA} \mathrm{~m}^{-2}$. Thereafter, $100,300,900$ or $2500 \mu \mathrm{L}$ of DWW were added. The current density profiles were similar for all the DWW aliquots supplemented. The profiles showed a maximum and then decreased slowly without reaching the base line. Without another substrate addition, the current density increased again to reach a maximum that was higher than the first peak observed. Fig. $2 \mathrm{~A}$ shows the chronoamperograms for $100 \mu \mathrm{L}$ DWW addition as example.

It was observed that the current generation decreased by increasing DWW volume additions. The lowest volume added $(100 \mu \mathrm{L}$ DWW $)$ resulted in an instantaneous current increase, while the highest volume added $(2500 \mu \mathrm{L})$ generated current densities even lower than the current observed during the biofilm formation (Fig. 2B).

As it was mentioned before, two current peaks were observed with only an initial substrate addition. It was noted that the peaks appeared earlier when low volume aliquots were added. The first peaks were formed between 1.8 and $4.7 \mathrm{~d}$, while the second peaks appeared between 6.5 and $11.9 \mathrm{~d}$. The current density reached for the first peaks was in the range from 1009 to $1289 \mathrm{~mA} \mathrm{~m}^{-2}$, and no relation between current and DWW volume added was detected. Conversely, the maximum current density of the second peaks decreased lightly with the volume added; in this case 1433 to $1796 \mathrm{~mA} \mathrm{~m}^{-2}$ was attained.

As shown in the Table 1, different MFC designs and inoculum sources have been used to test DWW as substrate. The performance of these systems varies from hundreds to thousands of mili-amperes normalized to the anode surface. The current reached in the present work was among the highest performance reported and similar to $1632-2040 \mathrm{~mA} \mathrm{~m}^{-2}$
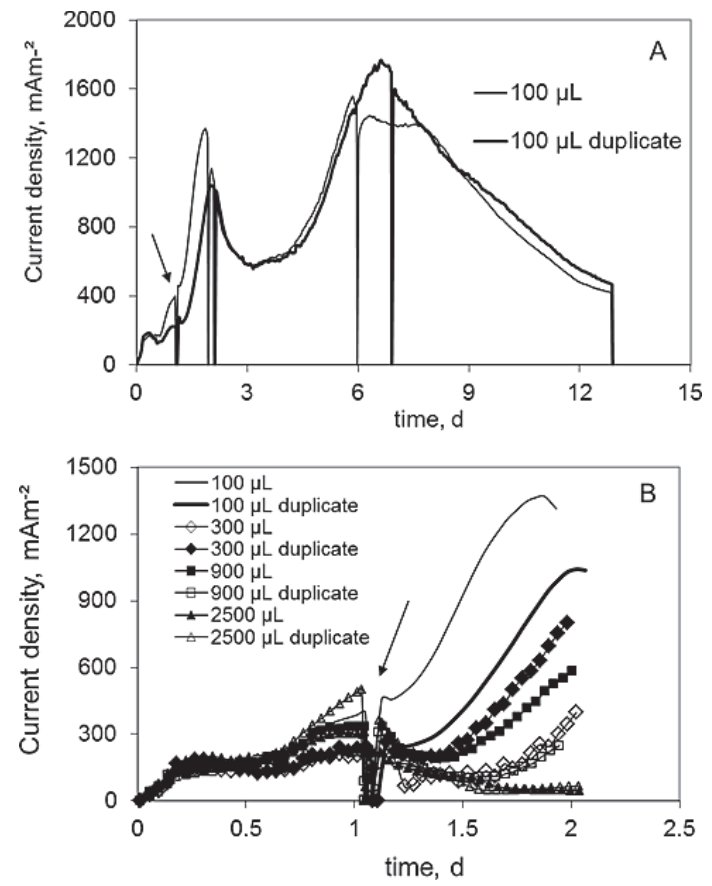

Figure 2. Current density from bioelectrode at $\mathrm{E}=+0.1 \mathrm{~V} / \mathrm{SCE}$ with DWW additions. A) Example of chronoamperogram for $100 \mu \mathrm{L}$ substrate addition showing two current peaks. B) First two days section of chronoamperograms showing the effect of increasing substrate additions on current generation. Arrows indicate substrate additions.

obtained for a two-chamber MFC [10].

The reduction of current density with high DWW volume added was observed in this work, which agrees with the reduction in the MFC performance with high COD substrate fed in a two-chamber MFC reported by Elakkiya et al. [16]. However, the contrary effect has been also reported. A MFC fed with molasses mixed sewage wastewater showed the highest power density with the full strength wastewater $\left(9968 \mathrm{mg} \mathrm{COD} \mathrm{L}^{-1}\right)$, followed by the half-diluted wastewater, and finally by the centrifuged sample [19].

The differences between the effects of strength wastewater on the MFC performance are very likely due to differences in wastewater composition. DWW contains proteins and lipids that in increasing concentrations could build-up the surface of the bioanode, thus hindering the mass transfer of soluble substrates toward the biofilm. Otherwise, the reduction of current density could be explained by the divergent electron fluxes from the microbial metabolism towards other compounds present in the complex medium, provoking a reduction of electron transfer to the anode [20].

Because the use of DWW to fuel MFCs seems to require a dilution step, the strategy followed by Sevda et al. [19] consisting in mixing high strength with low strength wastewaters could be applied to this particular system.

Comparisons considering the experimental charge produced as function of DWW volume added were also achieved. The current refers to the electron transfer rate, and the experimental charge indicates the total electrons transferred in a 
period, thus the maximum current could be high and the charge low or vice versa. In this work, the experimental charge had the same comportment than the current density with the DWW additions; both the experimental charge and the current density were lower for the first current peaks than for the second current peaks (Fig. 3A, B).

The two current peaks observed could be due to an evolution of DWW organic compounds. In an anaerobic environment, the organic matter evolves to volatile fatty acids (VFAs) and alcohols. These VFAs have been reported as substrate in MFCs, being the short chain acids easier to consume to produce electricity than the long-chain acids. That kind of stepwise oxidation was suggested by results of cyclic voltammetry in a MFC fed with fermentation effluents [21].

Moreover, long-chain organic acids are transformed to acetate by the microorganisms, and the acetate ultimately led to current generation. VFAs mixtures have shown to produce two current peaks; however the current reached in the second peak was much lower than the first current peak since only a small amount of acetate was newly formed [22].

A second possible reason for the two current peaks developed is a diauxic behavior of the substrates consumption, i.e., substrate is consumed in two or more phases caused by the presence of two or more substrates, one of them being easier to metabolize. Once the concentration of the first substrate descends, the microorganisms begin to consume the second one. Because the second current peak in this work was much higher than the first, and the main compounds in DWW are lactose and casein, it was investigated the possibility of a diauxic consumption of lactose and casein the former being easier to metabolize than the later.

\section{Effect of casein and lactose on the current generation}

In this stage, electrodes with biofilm previously formed were immersed in casein-lactose mixtures. It was observed that the casein concentration had a high influence on the current generation. Both, in the absence of casein $\left(0 \mathrm{~g} \mathrm{~L}^{-1}\right)$ and in its maximum concentration $\left(15 \mathrm{~g} \mathrm{~L}^{-1}\right)$, the current generation was lower than $40 \mathrm{~mA} \mathrm{~m}^{-2}$, but the middle casein concentration (1.5 $\mathrm{g} \mathrm{L}^{-1}$ ) resulted in $140 \mathrm{~mA} \mathrm{~m}^{-2}$ in four days (Fig. 4).

The current density without casein or lactose, i.e., the current due to the humic substances, decreased from 10 to $2 \mathrm{~mA}$ $\mathrm{m}^{-2}$ in $4 \mathrm{~d}$. Therefore it was assumed that humic substances did not participate in the current measurements.
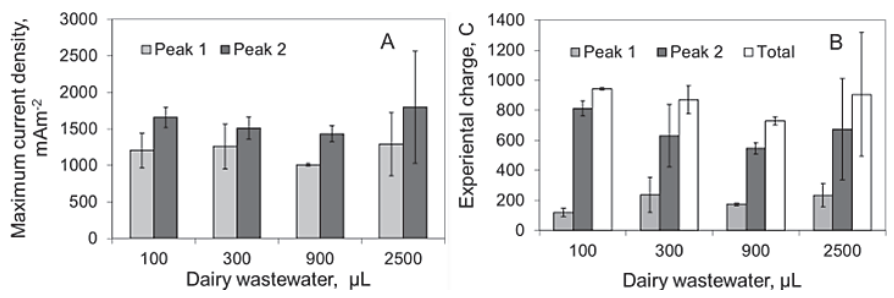

Figure 3. Performance of bioelectrodes fed with dairy substrates at $\mathrm{E}$ $=+0.1 \mathrm{~V} / \mathrm{SCE}$. A) Maximum current density for each current peak. B) Experimental charge for each peak and the total charge.
Both protein and sugar allowed current production. Using the maximum lactose concentration $\left(5 \mathrm{~g} \mathrm{~L}^{-1}\right)$, the startup of current generation had a delay of $4 \mathrm{~d}$ when casein was not added, and $1 \mathrm{~d}$ delay with a middle casein concentration (1.5 $\left.\mathrm{g} \mathrm{L}^{-1}\right)$. These observations suggest that the protein compound triggered the current generation (Fig. 5A). Furthermore, with the maximum casein concentration $\left(15 \mathrm{~g} \mathrm{~L}^{-1}\right)$ the current density was lower than $40 \mathrm{~mA} \mathrm{~m}^{-2}$, suggesting that an inhibition by high substrate concentration took place (Fig. 5B).

On the other hand, even in absence of lactose a current was generated, which indicates that the protein compound was used as a substrate for the current generation. One possible reason for this performance could be the acetate formation during the amino-acids metabolism, particularly the shorter alanine and glycine [23]. Being the acetate, the model substrate for MFCs, possibly the newly formed acetate led to the observed current after protein was metabolized.
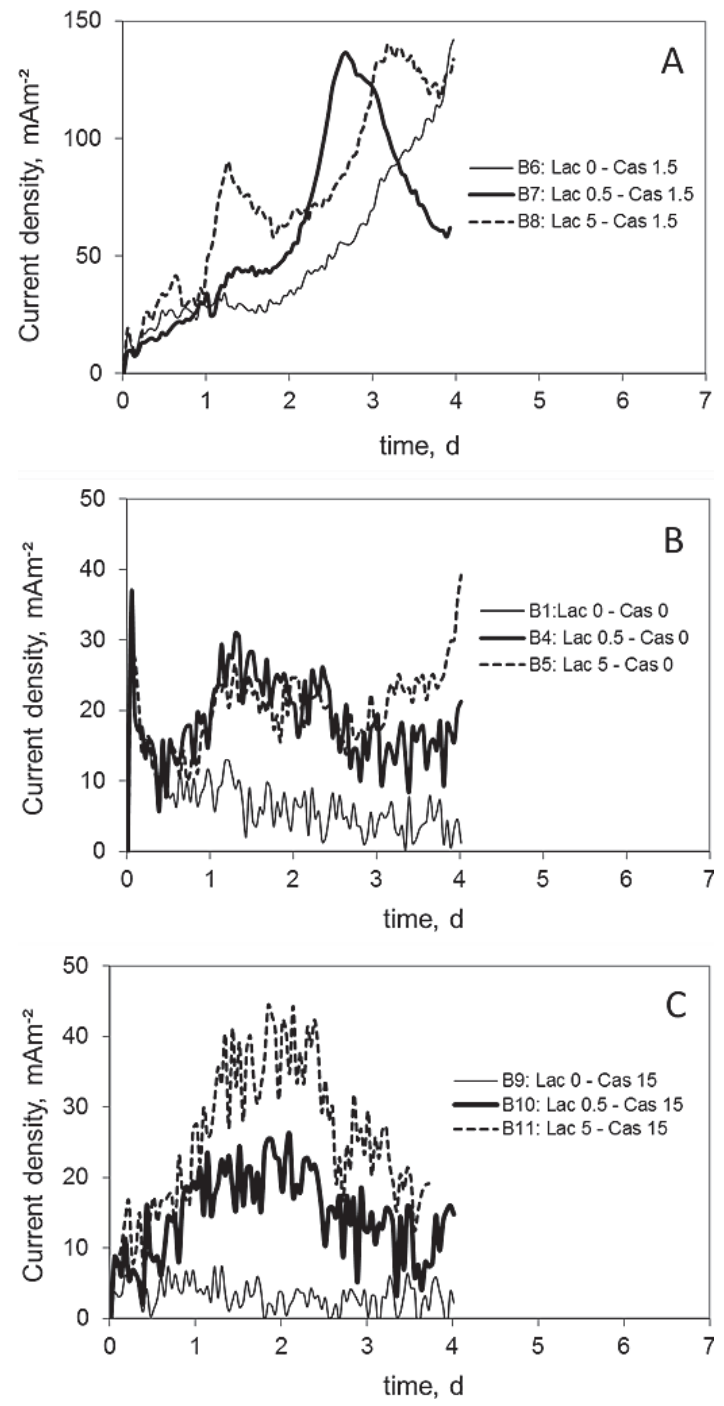

Figure 4. Current density from bioelectrodes at $\mathrm{E}=+0.1 \mathrm{~V} / \mathrm{SCE}$ fed with lactose-casein mixtures. A) $1.5 \mathrm{gL}^{-1}$ casein. B) $0 \mathrm{~g} \mathrm{~L}^{-1}$ casein. C) $15 \mathrm{~g} \mathrm{~L}^{-1}$ casein. (Note the scale in the $\mathrm{Y}$ axis). 

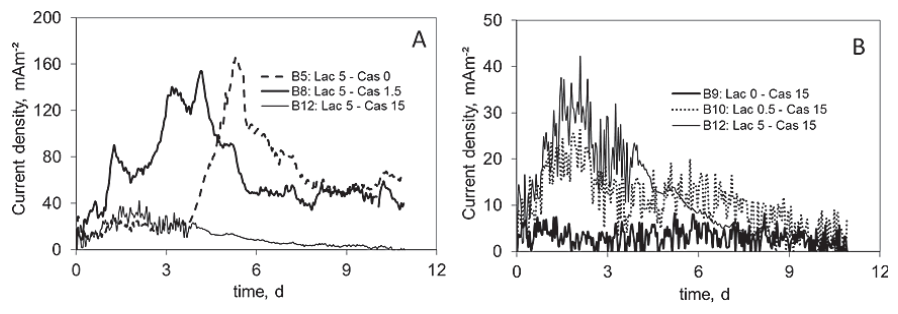

Figure 5. Current density from bioelectrodes fed with lactose-casein mixtures at $\mathrm{E}=+0.1 \mathrm{~V} / \mathrm{SCE}$. A) Maximum lactose concentration, 5 $\mathrm{g} \mathrm{L}^{-1}$. B) Maximum casein concentration, $15 \mathrm{~g} \mathrm{~L}^{-1}$. (Note the scale on the $\mathrm{Y}$ axis).

However, the maximum casein concentration $\left(15 \mathrm{~g} \mathrm{~L}^{-1}\right)$ inhibited the current generation, while the middle casein concentration produced current up to $320 \mathrm{~mA} \mathrm{~m}^{-2}$ (Fig. 6A).

In a similar comportment, without casein, a current generation was obtained, nevertheless in all cases a delay in the current startup was observed. The maximum lactose concentration $\left(5 \mathrm{~g} \mathrm{~L}^{-1}\right)$ provoked a decrease in the current density in comparison with the current reached using the middle lactose concentration, which was up to $1400 \mathrm{~mA} \mathrm{~m}^{-2}$ (Fig. 6B).

The maximum current densities obtained with each caseinlactose mixtures are shown in Table 2.

Overall, the current density reached with the bioanode immersed in the synthetic media, was lower than the current using the real DWW (1009 - $1796 \mathrm{~mA} \mathrm{~m}^{-2}$; Fig. 3A). These observations could be explained by the absence of suspended microorganisms during the experiments with a synthetic medium. Suspended and fixed microorganisms maintain ecological interactions to survive, to achieve metabolic activities, and to obtain the highest energy gain $[23,24]$. In addition, the biofilm ecology includes the detachment and attachment of bacteria to and from the medium; particularly for electrochemically active biofilms, the electron transfer to the anode may be affected by electron shuttles produced by planktonic bacteria [25]. Consequently the lack of suspended microorganism had an impact on the electron transfer, which was reflected as a lower current density. Additionally, the synthetic media lacked of other kind of nutrients (organic acids, lactalbumin, $\mathrm{Ca}$, etc.), and trace elements that certainly were present in the real DWW sample contributing to the biofilm performance observed.

Even though the current density was lower with synthetic media, this test revealed that the majority individual compounds
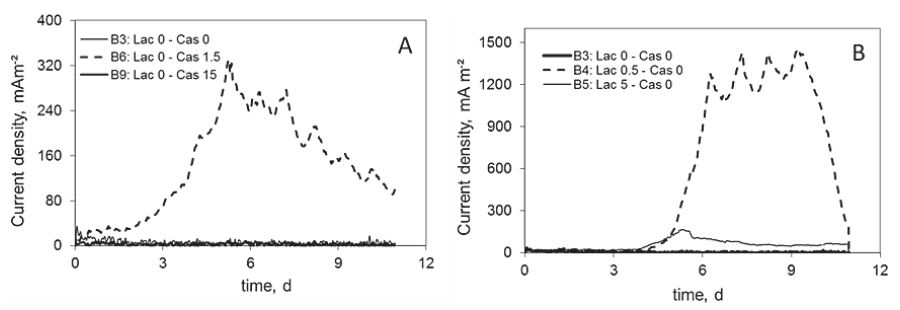

Figure 6. Current density from bioelectrodes at $\mathrm{E}=+0.1 \mathrm{~V} / \mathrm{SCE}$ fed with lactose-casein mixtures. A) Minimum casein concentration, $0 \mathrm{~g}$ $\mathrm{L}^{-1}$. B) Minimum lactose concentration, $0 \mathrm{~g} \mathrm{~L}^{-1}$. (Note the scale on the $\mathrm{X}$ axis). (casein or lactose) in DWW favor the current generation in comparison to the mixtures. In this way, the highest current density were obtained with $1.5 \mathrm{~g} \mathrm{~L}^{-1}$ casein and $0 \mathrm{~g} \mathrm{~L}^{-1}$ lactose, reaching $331 \mathrm{~mA} \mathrm{~m}^{-2}$ (or $0.132 \mathrm{~mA}$ ), and with $0 \mathrm{~g} \mathrm{~L}^{-1}$ casein and $0.5 \mathrm{~g} \mathrm{~L}^{-1}$ lactose, attaining $1276 \mathrm{~mA} \mathrm{~m}^{-2}$ (or $0.51 \mathrm{~mA}$ ).

Interestingly, previous reports on individual lactose and casein substrates have shown a similar trend (Table 1). A twochamber MFC fed with lactose produced $0.8 \mathrm{~mA}$ [8], and a single-chamber MFC fed with casein reached $0.11 \mathrm{~mA}$ [9]. These performances are quite similar to that obtained in this work; unfortunately no additional data on substrate concentrations were reported.

Overall, these results support the initial assumption of a diauxic substrate consumption using DWW, even the real DWW composition is more complex, the observations suggest that the current startup is promoted by the protein compound.

Analyzing the effect of casein on current generation, it was noticeable that without the limitation of substrate $(15 \mathrm{~g}$ $\mathrm{L}^{-1}$ casein), the current increased with the lactose concentration. However the maximum protein concentration resulted in the lowest current densities of all the casein-lactose mixtures. For all lactose concentrations, the current decreased with the increase of the casein concentration (Table 1).

The overall nutrient consumption was determined by the total organic carbon final concentration (TOC). Final TOC was

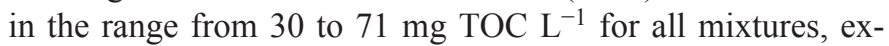
cept for the maximum casein concentration $\left(15 \mathrm{~g} \mathrm{~L}^{-1}\right)$, where final concentration was from 416 to $447 \mathrm{mg} \mathrm{TOC} \mathrm{L}^{-1}$. This information suggests that the maximum protein concentration was inhibitory to microbial activity, thus the substrate was not consumed and the electrons were not transferred.

Using synthetic media allowed evaluate in controlled conditions the current generation associated to the majority compounds in DWW. Nevertheless, no mixture generated the two-peak profile observed by using real DWW (Fig. 2, 3). Clearly, the effect of the diverse compounds in real industrial wastewaters on current generation in MFCs requires more systematic investigation in order to understand and optimize these bioelectrochemical systems.

\section{Conclusions}

In the present work it was evaluated the current generation by a bioanode formed from compost lixiviate as a function of real DWW additions. It was found that the highest current density

Table 2. Maximum current density generation $\left(\mathrm{mA} \mathrm{m}^{-2}\right)$ from bioanodes fed with casein-lactose mixtures at $\mathrm{E}=+0.1 \mathrm{~V} / \mathrm{SCE}$.

\begin{tabular}{cccc}
\hline & \multicolumn{3}{c}{ Lactose, $\mathrm{g} \mathrm{L}^{-1}$} \\
\cline { 2 - 4 } Casein, $\mathrm{g} \mathrm{L}^{-1}$ & 0 & 0.5 & 5.0 \\
\hline 0 & 7 & 1276 & 166 \\
1.5 & 331 & 137 & 154 \\
15 & 4 & 26 & 44 \\
\hline
\end{tabular}


is obtained with low substrate concentrations, moreover current profiles showed two peaks, being in the range from 1009 to 1289 $\mathrm{mA} \mathrm{m}^{-2}$ for the first group of peaks, and from 1433 to $1796 \mathrm{~mA}$ $\mathrm{m}^{-2}$ for the second group of peaks. In order to investigate the possibility of diauxic behavior substrate consumption, it was investigated the effect of casein and lactose on current generation using a synthetic medium. It was revealed that high protein concentration was inhibitory to current generation; the individual protein and sugar compounds led to the highest current density, $330.5 \mathrm{~mA} \mathrm{~m}^{-2}$ with $1.5 \mathrm{~g} \mathrm{~L}^{-1}$ casein, and $1276 \mathrm{~mA} \mathrm{~m}^{-2}$ with $0.5 \mathrm{~g} \mathrm{~L}^{-1}$ lactose. In addition, the protein promoted the current startup. These findings confirm that DWW is an alternative fuel to MFC, even though its complex composition. The differentiated current production as a function of dairy proteins and sugars could be useful to accelerate the startup of MFCs by selecting different dairy effluents according to their composition.

\section{Acknowledgements}

B. Cercado was supported by the European Union Programme of High Level Scholarships for Latin America (Program Alban), scholarship No. E06D101223MX. We thank the kind support of LGC-Toulouse for the use of their analytical infrastructure.

\section{References}

1. Pant, D.; Singh, A.; Van Bogaert, G.; Olsen, S.I.; Nigam, P.S.; Diels, L.; Vanbroekhoven, D. RSC Adv. 2012, 2, 1248-1263.

2. Pant, D.; Van Boagaert, G.; Diels, L.; Vanbroejhoven, K. Bioresour. Technol. 2010, 101, 6, 1533-1543.

3. Logan, B. E.; Murano, C.; Scott, K.; Gray, N. D.; Head; I. M. Water Res. 2005, 39, 942-952.

4. Heilmann, J.; Logan, B. E. Water Environ. Res. 2006, 78, 5, 531537.

5. Cercado-Quezada, B.; Delia, M.-L.; Bergel, A. Bioresour. Technol. 2010, 101, 2748-2754.
6. Pant, D.; Van Bogaert, G.; Porto-Carrero, C.; Diels, L.; Vanboekhoven, K. Water Sci. Technol. 2011, 63, 10, 2457-2461.

7. Cercado-Quezada, B.; Delia, M.-L.; Bergel, A. J. Appl. Electrochem. 2010, 40, 225-232.

8. Roller S. D.; Benetto, H. P.; Delaney, g. M.; Mason, J. R.; Stirling, J. L.; Thurston, C. F.; White, Jr. D. R. Proc. First World Conference on Commercial Applications and Implications of Biotechnology BIOTECH'83. Online Publications. London. 1983

9. Melhuish, C.; Ieropoulos, I.; Greenman, J. Auton Robot 2006, 21, 187-198.

10. Mathuriya, A. S.; Sharma, V. N. J. Biochem. Tech. 2009, 2, 133137.

11. Venkata Mohan, S.; Mohanakrishna, G.; Velvizhi, G.; Lalit Babu, V.; Sarma, P.N. Biochem. Eng. J. 2010, 51, 32-39.

12. Velasquez-Orta, S. B.; Head, I. M.; Curtis, T. P.; Scott, K. Bioresour. Technol. 2011, 102, 8 5105-5112.

13. Ayyaru; S.; Dharmalingam, S. Bioresour. Technol. 2011, 102, 24 11167-11171.

14. Nimje, V. R.; Chen, C. Y.; Chen, H. R.; Chen, C. C.; Huang, Y. M.; Tseng, M. J.; Cheng, K. C.; Chang, Y. F. Bioresour. Technol. 2012, 104, 315-323.

15. Mardanpour, M. M.; Esfahany, M. N.; Behzad, T.; Sedaqatvand, R. Biosens. Bioelectron. 2012, 38, 1, 264-269.

16. Elakkiya, E.; Matheswaran, M. Bioresour. Technol. 2013, 136, 407-412.

17. Thygesen, A.; Poulsen, F. W.; Min, B.; Angelidaki, I.; Thomsen, A. B. Bioresour. Technol. 2009, 100, 1186-1191.

18. Sapan, C. V.; Lundbald, R. L.; Price, N. C. Biotechnol. Appl. Biochem. 1999, 29, 99-108.

19. Sevda, S.; Dominguez-Benetton, X.; Vanbroekhoven, K.; De Wever, H.; Sreekrishnan, T.R.; Pant, D. Appl. Energy. 2013, 105, 194-206.

20. Freguia, S.; Rrabaey, K.; Keller, J. 11th IWA World Congress on anaerobic Digestion. 2007. Brisbane, Australia.

21. Pant, D.; Arslan, D.; Van Bogaert, G.; Gallego, Y.A.; De Wever, H.; Diels, L.; Vanbroekhoven, K. Environ. Technol. 2013, 34, 1314, 1935-1945

22. Torres, C.I.; Kato, M.A.; Rittmann, B.E. Microbiol. Biotechnol. 2007, 77, 3, 689-697.

23. Madigan, M. T.; Martinko, J. M.; Parker, J. Brock Biology of Microorganisms. 10th ed. Prentice Hall. N.J. 2003

24. Schneider, I.; Topalova, Y. Biotechnol. Biotechnological Equipment. 2013, 27, 3, 3782-3786.

25. Chen J.J.; Chen, W.; He, H.; Li, D-B.; Li, W-W.; Xiong, L.; Yu, H-Q. Env. Sci. Technol. 2013, 47, 1033-1039. 